\title{
Ten-year review of research in South Africa
}

\section{Government is tackling the R\&D crisis caused by a shift of focus to service delivery.}

Sir - As 27 April 2004 marks ten years of multiracial democracy in South Africa, it is appropriate to reflect on the poor state of science, engineering and technology research in the country, and how the post-apartheid government is reacting to this predicament.

With the demise of apartheid came a shift in research and development (R\&D) focus, from the military, energy selfsufficiency and food security, to basic service delivery. Although this shift was necessary, recent studies show that it corresponded with an alarming drop in the country's share of global scientific output, from $0.8 \%$ in 1990 to $0.49 \%$ in 2000 (A. Pouris. S. Afr. J. Sci. 99, 425-427; 2003). Expenditure on R\&D has also fallen, from $1.1 \%$ of gross domestic product in 1990 to $0.64 \%$ today (see www.naci.org.za/pdfs/ keyfactsfigures2002.pdf).

Nearly all South African scientific publications are authored by white males (about half of whom are now over 50 years old, up from 18\% in 1990). Femaleauthored publications remain low at $17 \%$. Today, only $5 \%$ of school leavers qualify to apply to study mathematics or science at university. The attrition rate among researchers is just as alarming: each year, some $11 \%$ leave government laboratories and 15\% leave universities. Of those, approximately $5 \%$ and $22 \%$, respectively, emigrate. The government has, fortunately, acknowledged the seriousness of this crisis and instigated several initiatives to remedy the situation.

Some of these initiatives aim to promote technology transfer and development. Since 1995, the government has launched a number of technology initiatives to reduce poverty, improve communications and promote biotechnology. Its industryoriented partnership programme has been hailed by stakeholders in industry and academia (see www.proudlysa.co.za/about/ news/2003/0729.html). Some of these initiatives are supported by new funding mechanisms (see www.saasta.ac.za/links/ funding.html), which offer opportunities for venture capitalists.

In 2002 the government released its first national R\&D strategy. This proposed, among other things, increasing the number of 'out of school' programmes to support mathematics, science and computer education; encouraging schools to produce more successful black and female students; and strengthening women's participation in all areas of science, engineering and technology. The strategy rightly notes that, given South Africa's limited resources, the successful promotion of R\&D requires focusing on the country's potential strengths, such as astronomy, human palaeontology, biodiversity, indigenous knowledge, HIV research, mining and Antarctic research. Other countries facing similar R\&D challenges should likewise identify and enhance their natural strengths.

Although it is too soon to evaluate the success of these initiatives, the country has notched up several notable achievements during the past five years, such as the construction of the Southern African Large Telescope (see www.gcis.gov.za/docs/ publications/pocketguide/sci_tech.pdf).

Another review a decade from now will, I hope, reveal that the country has increased its percentage share of global scientific output, won the bid to host the Square Kilometre Array radio telescope, redressed its skewed age and race publication demographics, and moved up the world's competitiveness rankings for technological achievement.

Jerome A. Singh

Howard College School of Law, and

Center for the AIDS Programme of Research in South Africa (CAPRISA),

University of KwaZulu-Natal, King George V

Avenue, Durban 4041, South Africa

\section{Injustice of draft law will speed Italy's brain drain}

Sir - Your News story "Wave of protest strikes Europe's universities" (Nature 428, 108 ; 2004) gave the impression that the problems in Italy with the draft "Moratti" law were the increase in minimum teaching loads and the withdrawal of autonomy from universities. These are important, but by no means the only issues of concern. As noted in the News story, a problem shared by many countries is the brain drain of talented young scientists from Europe a problem that is guaranteed to accelerate in Italy if this law is passed.

I give two examples. Italian professors have the option of forfeiting $40 \%$ of their academic salary in return for the right to spend some of their time in private practice, earning far more than they've given up. The new law will allow these part-time professors to go on plying their trade without any significant extra commitment to their university (minimal teaching levels are easily side-stepped) - but on full pay. At a time when universities are struggling with drastic cost-cutting measures, such as the two-year suspension of all recruitment and promotion, many academics find this generosity hard to digest. It can be financed only by further cuts in recruitment, already dangerously low.

Another dangerous proposal is to abolish the junior academic position of ricercatore (equivalent to assistant professor), without offering a serious substitute, such as a tenure-track programme. Not only does this leave junior scientists with little job security, in a country where almost all employees are permanent; it could also lead to a backlash by generating a large and unregulated body of casual workers, who could gain enough political power to force future governments to hire them all. This actually occurred in the 1980s, blocking recruitment for more than a decade.

Fortunately, science training in Italy is so good, and the raw material is of such fine quality, that its young people are rapidly snatched up by prestigious foreign universities. But it is regrettable that Italy itself has chosen not to profit from its most valuable resource.

David Burr

Department of Psychology, University of Florence, Via S. Nicolò 89, Florence 50125, Italy

\section{ITER, fusion for humanity}

Sir - Contrary to the suggestion in your News story "Partners fail to find common ground for fusion project" (Nature 428, 355; 2004), the United Kingdom cannot invite India to be its partner on ITER, the international fusion project.

As chief scientific adviser to the British government, I firmly believe that fusion power offers great prospects for humanity and have therefore been urging more countries to join the ITER effort. I am delighted that China, the United States and Korea have joined the European Union (EU), Japan and Russia as full partners.

If India wishes to join as a junior partner to ITER, this question should be formally raised with the EU and our international partners. At the moment, the minimum requirement for partnership is a commitment to provide, either in kind or in cash, a $10 \%$ contribution to the construction of ITER.

David King

Office of Science and Technology,

1 Victoria Street,

London SW1H OET, UK 